Ali Murat Özdemir/Gamze Yücesan-Özdemir

\title{
Turkish labour law: a political economy perspective
}

\begin{abstract}
This study aims to explore individual labour law in Turkey in the 2000s and the historical context within which the law is embedded. To this purpose, firstly, the process of the deterioration in the organisational capacity of the working class and the main trends in the accumulation strategies of post-1980 Turkey are investigated. Secondly, a functional analysis of the power relations embedded in norms regulating the field of the technical division of labour and the labour contract is pursued.
\end{abstract}

Keywords: individual labour law, collective labour law, capital-labour relations, flexibility, accumulation strategies, de-collectivisation, neo-liberalism, market relations, subordination, labour contracts, working conditions, working time

Introduction

On 22 May 2003, the National Assembly of Turkey passed a Labour Act (No. 4857) whose aim was radically to modify the "individual labour law' ${ }^{1}$ in accordance with a neo-liberal conceptualisation and envisioning of capital-labour relations, in which the ongoing process of the commodification of labour has been sanctified. In Turkish Law, Labour Act No. 4857 is the most basic and comprehensive statute regulating labour relations within the realm of the technical division of labour. Up to 2003, numerous amendments to the existing regulations intensified the process of commodification regulated by the law. Act No. 4857 covers the main components and limitations of labour contracts, such as the form of labour contracts, the payment of wages, working hours, rest days, annual paid leave, protection of children and pregnant women, workers' compensation and work rules. Contrary to many provisions of the collective labour law, it covers almost every worker and workplace ${ }^{2}$ and, in many cases, also applies to labour-capital relations in the informal sector.

The latest amendments to Act No. 4857 passed into law after the presidential approval of the revision bill that is called as the 'Pochette Law' on 25 February 2011.

This article aims to explore individual labour law in Turkey in the 2000s and the historical context within which the law is rooted. To this purpose, the process of the deterioration in the organisational capacity of the working class and the main trends in the accumulation strategies of post-1980 Turkey shall first be investigated. Historically, elements of the export-oriented industrial schema of reproduction, which requires significant changes in the norms regulating labour-capital relations in the realm of the

1 The law concerning workers' rights at work and through the contract for work.

2 Except journalists (Press Labour Act of 1952) and seafarers (Sea Labour Act of 1967), who have their own codes. Yet, in cases in which no specific solution is brought by the specific labour laws of journalists and seafarers, the new Labour Act shall apply. 
technical division of labour, became visible only after the impasse of the export-oriented version of the import substitution strategy, and after the erosion of the collective capacities of labour in Turkey in the mid-1990s.

Our investigation establishes that, as soon as the capitalist class in Turkey found the structural opportunities to submit several variants of the import substitution strategy, the Turkish state became interested mainly in lowering the collective capacities of the working class. It reached its aim, among other, violent means, by way of altering the collective labour law.

Within this period, the individual labour law of Turkey remained nearly untouched. Individual labour law regulates labour-capital relations in the realm of the technical division of labour. ${ }^{3}$ Only with the emergence of the crisis in the export-oriented version of import substitution can we observe the demands for a 'flexible' individual labour law. To put it differently, unless the state's function of securing the rights of capital to control labour power reaches a level in which the ruling classes benefit from the extraordinary ${ }^{4}$ absorption of relative surplus value, individual labour law remains untouched. This may be the case for other countries that have experienced the impasse of import substitution, yet it requires further investigation that is outside the scope of this study.

Against this background, the study will seek to perform a functional analysis of the power relations embedded in the norms which regulate the field of the technical division of labour and the labour contract. In other words, this study will functionally analyse the individual labour law of Turkey. It will be alleged that the provisions of the new labour law acquire a meaning when they are considered in correlation with the exportoriented strategy of accumulation.

The functional analysis will be pursued on three grounds. Firstly, the legal borders of the capacity of control in the technical division of labour will be analysed with reference to the changing content of the notion of subordination. Secondly, the shift in the regulatory scope of the labour contract will be dealt with. Thirdly, to conclude our attempt to reach a functional analysis of individual labour law, thus to reveal the power relations embedded in the norms regulating the realm of the technical division of labour and the labour contract, we will deal with the changing conditions of work to the extent that these norms and institutions influence the notion of flexibility.

An analysis of capital-labour relations on the axis of the impasse of the import substitution strategy

The socially-instituted forms of relations by which domestic labour is controlled in Turkey changed radically after the military coup in 1980. This was a time in which a major shift occurred across much of western Europe - particularly associated with

3 Absorption of relative surplus value is realised in the realm of the technical division of labour, whose spatial dimension can be exemplified - in general - as a factory, a place in which divisions of labour are regulated ex ante and work under single control or ownership; or a place in which the technical characteristics of capitalist production shapes the characteristics of the existing divisions of labour.

4 Extraordinary in the sense of super and/or hyper. 
governments on the right - in the relationship between capital and labour and their corporatist framework that had been prevalent since Marshall Aid came into existence. Again, this was a time which saw the emergence throughout the world of the discourses of informalisation and flexibilisation of labour relations. However, unlike Europe, the business initiatives did not include widespread initiatives to restrict, weaken or eradicate statutory protections for workers against arbitrary employer practices within the field of the technical division of labour or against the rigidities of the labour market in the 1980s in Turkey. Rather, in the post-1980 period, the main concern for Turkish policy-makers has been a massive reconfiguration of collective labour law as a device to weaken the collective capacities of the working class to interfere in national policies.

There are several reasons for this divergence between Turkey and Europe. In Turkey, collective labour law was not enacted with the idea of reaching certain levels of productivity that would help the Turkish bourgeoisie to compete internationally. Rather, the Turkish bourgeoisie was driven by the motive to benefit from the import substitution strategy. In fact, when considered from the perspective of the overall international competitiveness of Turkish industrial production, there were no additional gains which could be used in exchange for a deeper Taylorisation of the workforce and for the benefit of their import substitution-driven accumulation strategies (cf. Çetik and Akkaya, 1999: 206-214). Nor was Turkish industry determined to take the necessary steps for the kind of re-organisation that would help the pursuit of export-oriented strategies based on high levels of exploitation. On the other hand, the role of collective bargaining over the stabilisation of wage relations throughout the 1950-1980 period increasingly expanded, ${ }^{5}$ together with the rising organisational capacity of the labour movement. These led to the stabilisation of the production norms specific to import substitution, and had a correlation with the process of the constitutionalisation ${ }^{6}$ of labour - a process that ended with the military coup of 1980 .

The hegemonic projects pursued throughout the history of the Turkish Republic have always been successful in terms of depriving the dominated classes of establishing

5 Collective agreements found a certain area of impact in the stabilisation of wage relations in certain sectors in this period. The improvement in the overall schema of reproduction and the appearance of the paradigm of inflexibility, as a result of wage bargaining, were to a certain extent observable between 1950 and 1980 in the Turkish case (Boratav, 2003). Turkey witnessed the appearance of a peripheral kind of wage labour nexus (cf. Çetik and Akkaya, 1999: 56-57). Throughout the period, collective bargaining increasingly acquired a place in the determination of the wage-labour nexus as an intangible apparatus structuring interactions between state, trade unions and employee organisations. In some sectors, including automobiles and consumer durables, the social insurance system and the power to demand stable wages and that firing regulations should encompass a certain degree of job security were the elements of compromise in return for the management's right to intensified control over the labour process. The organisational rights provided by collective labour legislation have positively influenced the incomes of wage earners (Boratav, 2003).

6 In the narrowest sense, the term 'constitutionalisation' refers to the constitutional acknowledgement of labour rights. However, the term will be used in a wider sense, which includes the legal acknowledgement of abstract labour as a major constituent of society, by which juridical ordering seeks to intervene in the reality of social relationships by directly controlling and reconfiguring those relationships (cf. Hardt and Negri, 1994: 71). 
their own economic and political organisations capable of influencing policy-making on fundamental choices or 'discoveries'. This situation has continued and intensified in the post-1980s. When compared with the 1950-1980 era - which roughly corresponds to a certain variant of import substitution - a fairly weak level of representation and organisation of working classes in the state has become a persistent feature of post-1980 Turkish industrial relations.

However, the deprivation of the working classes from the means of participation in policy-making was not equal to the requisite level of control over the workforce to pursue an export-oriented policy as a strategy of accumulation. The Turkish bourgeoisie needed an impasse in the existing accumulation strategy and it needed also to wipe away the collective capacities of labour before beginning overtly to demand the creation of a mode of regulation that was compatible with an export-oriented industrial schema of reproduction. This would require significant changes in the norms that regulate labour-capital relations in the field of the technical division of labour. In other words, individual labour law has become a point of reference only after the effects of the reduction in the collective capacities of labour, combined with the impasse in the export-oriented version of the import substitution policy corresponding to the years between 1980 and 1994. These two determinants will be discussed briefly in order to understand the incentives behind the enactment of the new labour act regulating individual labour law.

\section{Impasse in the export-oriented version of import substitution}

Between 1980 and 1994, the neo-liberal 'revolution' in Turkey did not include the structuring of industrial organisations to charm international investment, while concerns over the weak national productivity level did not cause a break with the old patterns of production norms. The import substitution strategy was restored by a reduction in government involvement in productive activities, by an increased emphasis on market forces and by the replacement of an inward-looking strategy with an 'exportoriented strategy of import substitution' (Kepenek and Yentürk, 1996). With the continuation of the borrowing facilities of the state after the military takeover, which resulted in a relaxation of supply constraints, the Turkish bourgeoisie found a base on which to depend its earlier practices and it did not radically opt for the initiation of the investments necessary for the implementation of export substitution (Öniş, 1998: 77, 128). Within this context, the 'export-oriented strategy of import substitution' meant that the government aimed to achieve structural adjustment by liberalising finance without structurally changing the investment patterns of the Turkish bourgeoisie. ${ }^{7}$ Accordingly, we may observe the lack of supportive hegemonic discourses in the sphere

7 In the 1980s, the Turkish bourgeoisie's pattern of investment could hardly be deemed to be in compliance with the requirements of 'selling cheap labour' or 'skill intensive activities'. They did not invest in labour intensive sectors in which internationalised capital had declared its interest, nor did they articulate with internationalised capital under the conditions of vertical hierarchy (Ansal et al. 2000: 69-70). 
of relations constituting the technical division of labour, as in the case of 'Kigyoshu$g i{ }^{\prime}$ in Japan (cf. Woodiwiss, 1992). State economic enterprises were functioning (in an a posteriori sense) to transfer the cost of many intermediate goods from private to public under the protection of high tariffs. Yet, especially after the reductions in tariffs, the productive capacity of industry was severely weakened.

The stress created by unproductive investments over the division of total income created the 1994 crisis (Yeldan, 2001; Boratav et al. 2000). A massive depreciation of the exchange rate in the early months of $1994^{\circ}$ brought a major stabilisation programme in association with the IMF. After the 1994 crisis, the main dynamic of growth had become the ongoing reduction of wages and, thus, of the conditions for the reproduction of collective labour power as a result of the ongoing stress proceeding from the structural deficiencies in import substitution. The neo-liberal re-structuring of the Turkish state has resulted in an ongoing decline (except for the period between 1989 and 1993) in the portion of real wages and agricultural incomes throughout the 1980s, the 1990s and in the first years of the 2000s (Boratav, 2003). The ongoing decline in the portion of real wages remained the same under the rule of the Justice and Development Party (AKP) in between 2002 and 2011.

Post-1994 crisis management depended significantly on wage suppression, coupled with the re-invigoration of short-term foreign capital inflows. Labour markets became places in which significant shifts in income distribution were realised. ${ }^{10}$ Wage costs in US dollars decreased substantially and enabled export earnings to rise. In this manner, Turkey once again switched back to a mode of surplus extraction whereby the export performance of import-dependent industrial sectors depended upon savings in wage costs rather than on rising productivity. In fact, this disequilibrium could only have been accommodated by the massive flexibility displayed by the real remuneration of wage labour (Ansal et al. 2000: 59-63). Together with the decline in wage earners' income, inflows of foreign capital enabled the financing of the fiscal gap and the consequent current account deficit, and created the conditions for subsequent crises.

On the other hand, after the 1994 crisis, many companies made moves towards new production systems. In particular, multinationals and joint ventures with foreign capital may be considered avant garde workplaces in which new production systems were implemented (Yücesan-Özdemir, 2002).

When hit by the Asian financial crisis starting in August 1998, the Turkish economy was already under adverse conditions of severe macroeconomic disequilibria, with accelerating fiscal and current account deficits, high inflation and unemployment, and increased social unrest (Kazgan, 1999). The inherent characteristics of the growth-

8 'Kigyoshugi' refers to enterprisism, or a belief in the intrinsic virtue of the company, in Japanese industrial relations (Woodiwiss, 1992: 87). This term refers to the identification of the Japanese company as the principal object of the hegemonic discourse. It is clear that 'Kigyoshugi' is not the sole source of themes in the hegemonic discourse in Japan, but only that it is the dominant source of such themes and, therefore, of the interpellative means whereby the Japanese people are attached, and attach themselves, to their society.

9 Imports dwindled by $15 \%$, GDP fell by $5.5 \%$ and the inflation rate soared to $106 \%$ with the sudden drainage of short-term funds at the beginning of January 1994 (Yeldan, 2001: 51).

10 Real wages in manufacturing declined by $36.3 \%$ after the 1994 crisis (Yeldan, 2001: 44). 
crisis-adjustment cycles had quite different macroeconomic dynamics in practice than they did in the pre-1994 era. During the 1990s, changes in the level and direction of capital movements generated a financial cycle of boom/bust/recovery which, in turn, resulted in the rising instability of the growth rate (Boratav et al. 2000, Boratav, 2003; Yeldan, 2001, 2003).

From 1998 onwards, IMF-oriented economic policies played a significant role in the 'discoveries' of policy-makers in search of credit. ${ }^{11}$ Given that financial or capital account liberalisation had already been achieved, the pro-market rhetoric became inadequate for the initiation of the necessary measures. The Turkish working class had to be confronted with a new bill if the import-oriented structure of industry was to go on producing. In other words, in the absence of the investment patterns that would 'utilise' the labour residing in Turkey - and thus, of a change in the structure of industry itself - the placing of a greater reliance on 'free' labour market forces in policy-making became a political mantra serving the purpose of increasing the rate of absolute surplus value. The overall structuring of industry ceased to respond on a material plane to changes in the reproduction of capitalism on a global scale. To put it differently, Turkish industry bought machinery on credit, yet it could not utilise this by increasing its productivity, both in the international arena and on the domestic market. The overall use of the credit entering the economy did not serve the pre-validation of the values in the process which, as expected, would complete the full cycle of valorisation and realisation, since the Turkish domestic market was not big enough for their realisation and its industry was not open to external markets.

\section{Reduction in the capacity of labour to take collective action}

These circumstances correspond to significant changes in the collective capacities of labour.

Firstly, unions in Turkey have been facing a very hostile legal environment since 1980. The military intervened in the main codes constituting the Turkish collective labour law. The labour containment strategy for the post-military regime era was certainly not in conformity with some form of a state corporatist framework, but with the general thrust of the 'new right' politics aiming to put the organised action of workers in its place (Yalman, 1997, 2002). ${ }^{12}$

Secondly, the more work relations are made flexible in Turkey, the faster society changes into a de-unionised and unorganised risk society for which the cost in terms of individual lives is incalculable. Today, paid employment is becoming more and more

11 The main axis of IMF policies, especially after the February 2001 crisis, aimed to reach stabilisation by way of rebuilding market confidence. In practice, this strategy was legitimised under the banner of the strategy of competitive disinflation aimed at creating a price advantage over the leading transnational competitors. This policy assumed the de-indexation of wages, a decrease in employer costs and the strict control of budgetary expenditures.

12 The new 1982 Constitution and the enactments of the Collective Labour Agreement, Strike and Lockout Law No. 2822, of 7 May 1983, and of the Trade Union Law No. 2821 of 5 May 1983 , all of which came into effect at the end of the military period, are all in conformity with this change. 
precarious; and the foundations of the quasi-social welfare state of Turkey have collapsed.

Thirdly, the new workplace, under 'total quality management' or 'human resources management' initiatives, has generated new challenges and constraints to unions in Turkey since the mid-1990s. The emerging capital and labour relations in the contemporary workplace, which draw on an ideological discourse formulated to increase shared interests between managers and workers and to promote the end of 'them and us' attitudes and behaviours, attack the union's presence on the shop floor. ${ }^{13}$

Fourthly, the lack of job security is an important social fact militating against unionisation.

Last but not least, in the absence of class politics, the struggle of trade unions in Turkey has been uni-dimensional (collective bargaining) and taking place at one level (that of the collective agreement) and on one issue (wages). In post-1980 Turkey, the 'lack of democracy', the 'uneven distribution of wealth', and 'human rights' have never been challenged by the questions raised by, nor the policies developed by, the unions (Dereli, 1998).

\section{Emergence of the concerns for individual labour legislation}

The 1994 crisis occurred as a crisis of confidence in the viability as a dominant strategy of export-oriented import substitution. Import substitution as a hegemonic project disappeared from the discourse but, as a social reality, remained to be decisive in the reproduction of capitalist relations of production, despite the emergence of investment as a part of international commodity chains. The new institutionality in work, together with the refusal of the aim of deepening import substitution, decreased the portion of skilled workers among overall workers. Given that trade unions weakened significantly, the informal sector expanded, the pressure of the reserve army on working power intensified and the limited rigidity paradigm of the 1970s lost its meaning.

From 1994 onwards, the axis of accusations in the search for an excuse for the clear failure of neo-liberal policies has become the rigidities of labour legislation. This refers to the need to restrict, weaken or abolish statutory protections for workers against employer practices in the realm of the technical division of labour and in the labour market. Accordingly, the Turkish bourgeoisie's calls for a flexible individual labour law have intensified (TISK, 1995, 1997, 1999; TÜSİAD, 2002; Yeldan, 2001: 25). Within this context, regulations in the organisation of the technical division of labour became to be considered as a source of impediment to the 'successful' transformation of the existing accumulation strategy into an export-oriented strategy (Yavan, 1999).

The labour market is 'rigid' with respect to many potential factors: if the level of unemployment-insurance benefits is too high, or their duration is too long; or if there are too many restrictions on the freedom of employers to hire and fire; or if the permissible hours of work are too tightly regulated, or if excessively generous compen-

13 The new workplace where ample emphasis is given to the 'manufacturing of consent', has a hegemonic nature. In these hegemonic factory regimes, most of the experienced, older workers note that the new recruits do not know of the struggle together with the union, feel more sympathy for the company and have more pro-company attitudes (Yücesan-Özdemir 2002). 
sation for overtime work is mandated; or if trade unions have too much power to protect incumbent workers against competition and to control the flow of work at the site of production; or perhaps if statutory health and safety regulations are too stringent... None of these items are present in Turkish industrial relations. The labour market indicators of Turkey leave no room for argument in trying to explain the need to evaporate the so-called 'rigidities' in the formal labour market.

Unlike the legal provisions in the field of collective labour law, the regulatory power of the individual labour law legislation has a vast area of application, including the informal sector, provided that the worker succeeds in bringing his case before the court. Symptomatic of this situation has been the increasing demands of the private sector to modify the legal conditions of the labour contract, a view that, on several occasions, has been openly echoed by their representatives (TÜSİAD, 2002, 2010).

Against this background, and from the 1990s onwards, the protective provisions of individual labour law have remained in a context in which the recognition of conflict and its inevitability in an industrial society have been omitted from the consideration of jurisprudence. Individual labour law was affected by this discursive shift from a social democratic to a neo-liberal labour law discourse in the envisioning of the economy which addressed capital-labour relations. The significant changes in the discursive framework in which judges made their decisions have allowed the judiciary to apply what was, in fact, a socially pragmatic methodology of law, finding rather than invoking a set of substantive principles. ${ }^{14}$

Against this background, firstly, the definition of individual labour law in jurisprudence has changed. Today, labour law is defined as the law regulating relations between the worker and the employer on the basis of market relations (Ulucan, 2000: 299-312). This definition implies that regulation in the sense of individual labour law states only the aim of reaching a system in which labour is a pure commodity and has no collective identity vis-à-vis the individual capitalist who is a fraction of collective capital. The application of the existing protective provisions of the labour law (case law) has begun to change in the direction of the law of obligations, meaning that the neo-liberal discourse in labour jurisprudence has become influential.

Secondly, an intersection between the changing application of court rulings and the changing content of the discourses of production have become observable. Even in the case law and the judicial comments on the law of obligations, which cover the sale of real commodities, ${ }^{15}$ the re-evaluation of any kind of contract depends upon the principle of protecting the weaker party. However, the re-evaluations pursued by the Court of Cassation protect industry rather than workers. ${ }^{16}$ Legitimisation is achieved via an argument that refers to the importance of the protection of the enterprise which would, in turn, lead to the protection of the worker (Özveri, 2002: 207-256). A kind of public

14 For similar developments in the United States and Japan, see Woodiwiss (1992).

15 Legal forms developed in private law, in general, cannot be directly applied to the field of labour law.

16 The Court of Cassation's attitude toward the enforcement of collective agreements in favour of workers in times of crisis is also in conflict with the existing labour regulation, including the provisions of the Constitution (Articles 90, 119, 121); ILO Conventions ratified by the country (No. 87 and 98); and the Maritime Act No. 2935 (Articles 10, 11). 
interest test is then established in this argument under the principle of social utility. We can clearly track signs of neo-liberal arguments which try to ignore the conflictual characteristic of industrial relations in the justifications of the Court of Cassation. In the same vein, the legal doctrine has started to change its explanations on the main principles of the labour law by referring to the importance of the public interest tests as a counterbalancing force to the principle of the protection of workers. More so, the burden of the protection of the enterprise, in conformity with the developments explained above, is now on the workers rather than on the state, which would provide protection by way of taxes, credits, providing information, etc.

All in all, capital is always born from and developed on the basis of exploitation, transforming the concreteness of that social relationship into the abstraction of its own configuration (Hardt and Negri, 1994: 104). Turkey has formed its labour law of the post-1980s era under conditions of 'de-constitutionalisation' 17 in which labour, even in the form of abstract labour, is condemned in its liberal and narrowest sense to insignificance in the discursive conceptualisation of the economy. Living labour has become to be seen as a cost (of production) and is forgotten as a source of demand (Jessop, 2002).

Thus far, the inquiry into the changing envisioning of the legal regulation of capitallabour relations has served in this article as a basis from which to examine some general properties of labour law, but we turn in the next section to a consideration of the new Labour Act of 2003.

\section{A functional analysis of the new labour act}

The first Labour Act (No. 3008) came into force on 15 June 1937. The Act was prepared when a distinct Turkish bourgeoisie and working class had not yet emerged and when the conflict-limiting potential of populism and statism was used to control the development of labour organisations.

The subsequent Labour Act (No. 1475) came into force on 12 November 1970. This bore the imprints of a reasonably social democratic discourse, and stayed in force for almost twenty-five years, up to 2003.

The new Labour Act (NLA) was enacted on 22 May 2003. Contrary to the previous acts, the NLA is committed to a neo-liberal conceptualisation and imagination of capital-labour relations in which labour is seen as an ordinary commodity, reckonable in terms of production costs. The NLA covers many areas of worker-employer relations belonging to the field of the technical division of labour, and to labour-capital relations in the labour market. The new provisions, in conformity with the current discourses of 'flexibility' and 'human resource management', include the transformation of workers' obligations; subsequent changes in the main conceptualisations of individual labour law; a shift in the regulatory scope of a labour contract; and the introduction of new

17 The process of the legal de-constitutionalisation of labour in Turkey responded on a material plane in which collective labour law had lost its function as a determinant of Turkey's peripheral/sectoral type of wage labour nexus, and on which individual labour law is conceptualised in a context in which its class dimension is denied in terms of changes in the international division of labour. 
types of labour contracts and of new conditions of work. All of these refer to a change in the norms of production and consumption determining the ratio of surplus value to capital (the rate of profit). This means that the process of change in the relatively durable pattern of structural coherence in the handling of the contradictions and dilemmas inherent in capital-labour relations in the peripheral capitalism of Turkey has come to a point of culmination.

This section seeks to perform a functional analysis of the individual labour law, i.e. of the power relations embedded in the norms regulating the field of the technical division of labour and the labour contract. It will be alleged that the new provisions are in accordance with the emerging strategy of the establishment of an export-oriented industrial schema of reproduction. Our investigation in the area of the legal parameters of the capacity for control will be pursued on three grounds.

We will firstly examine the changing conceptualisation of subordination, to investigate the legal boundaries of the scope for control in the technical division of labour.

Secondly, the shift in the regulatory scope of the labour contract within the context of the labour market, and the subsequent introduction of new types of labour contracts referring to the changing scope of regulatory power over the contract of employment, will be dealt with. This second task also contains a survey of the legal subjects that are excluded from the protections brought about by the provisions that have put boundaries to labour contracts.

Thirdly, to conclude our attempt to reach a functional analysis of individual labour law, so as to reveal the power relations embedded in the norms regulating the realm of the technical division of labour and the contract of employment, we will deal with the changing conditions of work to the extent that these norms and institutions influence the notion of flexibility.

\section{Subordination: redefining the concept}

Workers' subordination to the employer in the performance of a certain job is the fundamental pre-requisite of working relationships. The power to determine the actual deployment of labour in the production process depends particularly on this obligation of the worker. Only by way of subordination can the conditions for the extraction of surplus value be established. The notion of subordination appears as the nodal point at which the individual capitalist's right to control labour power finds its legal expression. Thus, the way that the concept of subordination is conceptualised is central to the legislation concerning labour-capital relations in the workplace.

The subordination inherent in capital-labour relations in the workplace is mainly established by authorisation of the labour contract. The worker is considered to be a person who works under a labour contract (Article 2 of the NLA). In the previous Labour Act (No. 1475), the concept of the individual contract of employment was not defined and the judiciary would refer to Article 313 of the Obligations Act, which stated that the labour contract was:

A type of contract whereby the employee undertook to perform a 'definite or indefinite' service in return for the employer's obligation to pay a certain wage. 
The change in the meaning of the concept of subordination can be traced in the definition brought by the NLA. The first sentence of Article 8 of the NLA defines the labour contract as a:

Type of contract whereby a party (employee) undertakes to perform, under subordination, a service in return for which the other party (employer) undertakes to pay him a certain wage.

The removal of the terms 'definite or indefinite', which were stated in Article 313 of the Obligations Act, indicates that subordination cannot be limited by defining a certain form of it as definite. The role of the 'nature of the specified service', which would be carried out by workers in compliance with the legal framework established by workplace rules, case law and the protective measures brought about by the law, ceases to be determinant in the assessment of the limits of subordination under these conditions. Concerning the removal of the terms 'indefinite and definite service', the concept of subordination is in the process of acquiring a new meaning in which the powers of the employer over the determination of the conditions of work are on the increase, despite a decrease in the restrictive role of the notion of 'the nature of work' in question.

The discourse of the NLA disregards the principle of the protection of the worker in the light of the principle of social utility. Classical labour law aimed to protect workers due to the power imbalances in the nature of the work relationship (Esin, 1982; Talas, 1992; Tunçomağ, 1971). This approach was consistent with the specific character of the 'commodity' in question. Today, the protection of the worker is considered to be related to the protection of the existence of the enterprise which provides the worker with a wage. The change in the importance of the principle of the protection of the worker can be considered with reference to the change in the notion of subordination. The legal impediments over the individual capitalist's enjoyment and use of labour power disappear in the face of the priority given to the protection of the enterprise.

\section{Terms of employment}

Employment practices, whether acknowledged and regulated by the NLA in the form of a certain type of labour contract or approved implicitly by policy-makers and the courts, remark on the forward march within the peripheral capitalist economy of Turkey to the 'ecological dominance of capitalism' (Jessop, 2002). To investigate these practices, we deal here, firstly, with the juridical forms which have been used to bypass the normative constraints prior to the enactment of the NLA due to their frequent applications in practice: fixed-term contracts; contract work; sub-contracting; and homeworking. Secondly, the forms established by the NLA will be discussed: temporary employment relationships; contracts specifying attendance at the call of the employer; compulsory work; and extra hours working.

First, a change in the dominant legal form regulating the construction of labour contracts may be observed: the new dominant legal form is emerging in the form of fixed-term contracts, while labour contracts for an indefinite period are losing their place as the principal form. A contract for a definite period (that is, a fixed-term contract) has a specified duration, while a contract for an indefinite period is open-ended. 
A contract signed for a definite period expires automatically at the end of the duration specified in the contract, without obliging the employer to pay severance pay, whereas the cancellation of contracts signed for an indefinite period by the employer generally end up in severance pay in legal practice.

The slip to fixed-term labour contracts is providing the necessary discursive apparatus to lawmakers (in Turkey and around the world) to pursue new restrictions on protective provisions under the banner of liberalising principles. The protective provisions of the ILO Conventions and EU acquis communautaire generally direct their regulatory influence toward labour contracts signed for an indefinite period. Thus, accepting the protective provisions of the ILO Conventions regulating contracts for an indefinite period, while transforming the dominant domestic legal form of labour contracts from contracts signed for an indefinite period to fixed-term contracts, has helped lawmakers bypass the limitations brought by these agreements. Indeed, the introduction of flexibility clauses into ILO Conventions has provided the room for this massive change.

Contract working as a temporary model of employment (and encompassing some characteristics of fixed-term contracts) became an over-riding recruitment strategy in those public sector companies that were scheduled to be privatised after the mid-1980s (Cam, 2002). Contract working is an interim category used to transfer the legal status of public servants to the category of worker. In contract work, the expiry of the time mentioned in the contract automatically brings the work relationship to an end without any further costs. A significant proportion of white-collar workers in state economic enterprises were employed on contracts, and blue-collar workers were included in this strategy by the extension of contract working at the end of the 1990s (Boratav, 2003).

Another form employed over the last ten years as a means of increasing the pressure on the labour market has been the system of subcontracting. The coercion practised by way of implicit authorisation on the demand side of the labour market to pursue strategies aiming at bypassing the legal regulations on the rigidity of the labour contract are apparent in these forms of work. Consequently, the pressure of the labour market on individual workers has provided individual capitalists with the necessary social means to use subcontractors. Secondly, the generality of the conditions set up by the contractualism inherent in neo-liberal discourses of production - that is, the universal principle of the freedom of contract - has provided the same individual capitalists with the legal means to fill their vacancies through workers provided by subcontractors and/or homebased workers instead of permanent ones. Thirdly, in the Turkish case, de-regulation has not implied additional hiring, and thus has not led to the development of employment, yet it has corrupted the existing conditions of work by creating vacancies that would be filled by temporary workers or by workers provided by subcontractors. Fourthly, subcontracting has been intensively used by privatised companies.

Another form of labour to be mentioned is homeworking - a form of work relationship in which work is carried out in the dwellings of the workers. Workers are paid on the basis of piecework after the submission of the products of their labour to the individual capitalist and/or the small merchants who, in many cases, work for individual capitalists. The responsibility of the individual capitalist is limited to the payment of 
the necessary amount. Mainly after the 1990s, with the general acceptance of flexible production norms in some industries, including in the production of consumer durables, employers narrowed their core workforce and the application of homebased work in industrial cities increased significantly (Selçuk, 2002: 22). Homeworking is prevalent in artisanal production, such as carpets or embroidery, as well as in the garment and footwear industries. Homeworking is generally conducted through privately-run outsourcing networks.

In accordance with these changes in the social context after the 1990s, the NLA introduced the concept of the temporary employment relationship to Turkey's industrial relations literature. The new Act provided employers with more than what they expected; that is, the right to 'transfer' the worker to another employer without abolishing the existing contract (Article 7). ${ }^{18}$ The NLA enabled employers to transcend the benefits of the subcontracting system, which is appropriate for only small businesses capable of serving mid-range and big companies and which is not operational for industry. Subcontractors are incapable of providing industry with skilled or semi-skilled workers trained for operational conditions in industrial workplaces. With the materialisation of the temporary employment relationship, industry has acquired the power to use core workers without bearing the costs of paying wages in times of recession.

Moreover, this formulation is also in conformity with the organisational patterns of Turkish industry. ${ }^{19}$ Groups are now able to 'transfer' the labour power they already have in 'stock' from one of their companies to another. Thus, they have acquired, vis$\grave{a}$-vis their workers, the right to demand the performance of various jobs under the same labour contract. The neo-liberal argumentation that flexibility creates jobs is completely inconsistent with the situation in such a transitory work relationship. The preamble of Article 7 clearly demonstrates this 'support' by overtly stating that the labour contract, like other sales contracts, can be assigned to a third party. The duty of workers to perform a certain task in a certain place for a certain employer is now, under the conditions of a transitory work relationship, transferred to a duty to be in any place and to perform any task required by any employer.

Another difference in this legal 'discovery' from previous forms of subcontracting is that, unlike in subcontracting, the worker's obligation to obey the orders of the employer is doubled, meaning that $\mathrm{s} /$ he is now under an obligation to serve two employers

18 The transitory work relationship brought by the NLA into Turkey's law can be best illustrated by a short comparison with the shukko (the transfer of workers to related firms) under Japanese law. Woodiwiss (1992) argues that, in Japanese law, which is the prime location for a patriarchal labour law discourse, shukko is the point at which the patriarchal obligation of employers to provide 'lifetime employment' comes into force. In Turkey, in the absence of such a patriarchal obligation, as well as of high wages and life-time employment, this new obligation seems to increase the deterioration in the working conditions of workers and produces new legal problems whose solution lies not in the contractual condition, but in the way in which individual judges understand the needs of the economy and the public interest.

19 The Turkish industrial bourgeoisie is not simply a distinct faction of total Turkish capital; rather, it is organised in 'groups', which are capable of investing capital both in industry and, when needed, in financial institutions (Sönmez, 1998: 26-31). 
with one labour contract. ${ }^{20}$ It may be alleged that Article 7 is conditioning the written approval of the worker for the establishment of a transitory work relationship, and that this written approval can be considered as a new labour contract. The bizarre point here is that one cannot sign a new labour contract without ending the previous one. In contrast, EU regulation 2001/23/EC, dated 12 March 2001, regulating the transfer of work or of labour contracts, does not entail the novelty of creating two employers for one worker. $^{21}$

The NLA enables employers to develop contracts under which workers would come to work only where they are called to do so. The new Act formulates that attendance at the call of the employer is a:

Work relationship in which the workers' duty to work begins when the service of the worker is required by the employer,

and that this kind of work relationship should be realised by way of a part-time labour contract as the most convenient legal form (Article 14). This legal form allows the employer to determine the time and the duration of the total work demanded from the worker. In cases where the duration of work is not determined clearly by the labour contract, the duration of weekly work is considered to be twenty hours (Article 14).

In addition, the recent change that is brought by Article 172/k of the Pochette Law dictates that students working part-time in universities shall not be considered as workers.

Work at the call of the employer leaves the worker in a position of total uncertainty as to when s/he will be called to work. Moreover, this contract defines the worker as an economic being who does not have any social and/or private life and who is always ready to be called to work.

Another striking feature of the NLA is that it introduces a new conceptualisation to Turkish Law: extra hours working. Article 41 of the NLA states that:

Overtime work is work that exceeds forty-five hours a week. ... In cases where the weekly working time has been set at less than forty-five hours by a contract, work that exceeds the average weekly working time ... is deemed to be work at extra hours. In work at extra hours, each extra hour shall be remunerated at one and a quarter times the normal hourly rate....

In cases of labour contracts that are for less than 45 hours, the wages for overtime work are just 25 per cent above the normal hourly rate. In cases of labour contracts that are for more than 45 hours per week, overtime working is remunerated at 50 per cent

20 '.... The second employer] has the right to give instructions.' (Article 7/1)

21 Directive 2001/23/EC relates to the safeguarding of the rights of the employee in the event of the transfer of undertakings. The defendants of the new Labour Act have referred to the Directive to prove the universal application of the transitory working relationships regulated by the new Labour Act. Yet, given that the dual obligation of the worker in transitory work relationships does not exist in Directive 2001/23/EC, reference to the EU directive seems to be illusory. 
above the normal hourly rate. In other words, if an employer sets regular working time as less than forty-five hours a week in the labour contract, s/he will be entitled to demand that the worker work extra hours for less, of course under the vague conditions set up by the law. Accordingly, to work for 45 hours a week is considered as a duty of the collective worker under the NLA. In this way, a peculiar/negative kind of protection for workers appears: one in which the limitation actually works for the benefit of the employers, meaning that the protective provisions have become protective for the individual capitalists.

\section{Working conditions}

Another step in the erosion of the rights of the individual worker in the workplace is the change in the norms regulating the conditions of work. In classical labour law, the worker's obligation ends when s/he provided her/his service at the direction of the employer, whether or not the employer used her/his service. The NLA empowers individual capitalists to regulate working hours in such a way as to bypass the restrictions on overtime work with no additional costs. This change was demanded by the bourgeoisie in various meetings and documents after the 1994 crisis (TISK, 1995, 1999a, 1999b; TÜSİAD, 2002).

The new regulation of working time (Article 63) is an 'invention' and/or a 'discovery' which prevents the worker from gaining wages in some particular cases where the employer lacks the ability to use his/her labour power. ${ }^{22}$ We may observe here the way the different structural power differentials are shaped by the labour contract and the relevant legislation under a neo-liberal legal discourse. In other words, the correlation has become apparent between the new legal discourse and the changing content of the right of the individual capitalist to control labour power within the framework of the codes regulating labour relations in society. ${ }^{23}$

The NLA enables employers to regulate the distribution of weekly working hours at their discretion, up to eleven hours a day (Article 63/2). The new Act also states that the employer can force the worker to work eleven hours a day provided that, within a time period of two months, the average weekly working time of the employee does not exceed normal weekly working time. What is more, this two-month period can be extended to four months when included into a collective labour agreement (Article $63 / 2)$.

22 Article $63 / 2$ of NLA states: 'Provided that the parties have so agreed, working time may be divided by the days of the week worked in different forms on condition that daily working time does not exceed eleven hours. In this case, within a time period of two months, the average weekly working time of the employee shall not exceed normal weekly working time. This balancing (equalising) period may be increased up to four months by collective agreement.'

23 Given the poor levels of productivity in Turkish industry, the further extraction of surplus value from workers under the current conditions requires an increase in the currently-extracted levels of absolute surplus value from the collective worker. This issue is clearly in harmony with our investigation into the socio-economic level at which Turkish capital-labour relations operates. This stresses the crisis in productivity due to the impasse in the accumulation strategy that is represented by import substitution. 
Secondly, the new Act clearly empowers employers to regulate working hours within the 24-hour time period at their discretion (Article 67). ${ }^{24}$ The flexibility brought by this Article is known as a 'slippage in the duration of work' in central capitalist countries, and has been in application since the early 1970s (Tuncay, 2003: 3-18). The power of the employer is enlarged in two dimensions by this legal technology. The first dimension is the power to determine the starting time of the working day (simple slippage). The second dimension is the power to determine not only the starting hours of the working day but also the duration of the working day (qualified slippage). By stating that the starting and finishing time of daily work is declared to workers by the employer, Article 67 of the new Act opens the way for qualified slippage.

Thirdly, the NLA does not only empower the employer in the regulation of working hours, but also in the regulation of non-working hours; in other words, of break times. The NLA, in conformity with the demands of Turkish industrialists (TISK, 1999) and with EC Directive No. 104, leaves the regulation of break periods to the employer. This situation is clearly associated with the new institutionality, which signifies changes in mass production patterns in which masses of workers start work, eat and leave work all at the same time.

\section{Conclusion}

This study has attempted to establish a framework in which labour law can be understood with regard to the social relations surrounding its provisions. In the course of this study, the task of elucidating the structural constraints and powers of individual and collective subjects within the sets of relations amidst which they live required the posing of two implicit historical questions: Why and under what circumstances was the NLA introduced to industrial relations at a particular point in time? And what were the particular legal interventions of the NLA in terms of achieving greater levels of flexibility in Turkey in the 2000s?

In this context, the article has argued that the deterioration in the organisational capacity of class forces (together with a decline in the protective capacity of collective labour law) has led to an extraordinary application of individual labour law within labour-capital relations. The labour law of the post-1980s was shaped under conditions of the de-constitutionalisation of labour in which labour, even in the form of abstract labour, is condemned to insignificancy in the discursive conceptualisation of the economy in its liberal and narrowest sense. When the legal constraints embedded in the wide range of protective provisions regulating collective bargaining and individual labour legislation are eradicated, the changes imply the rule of the market.

Before the 1994 crisis, the Turkish state's function in securing the rights of capital to control had never reached a level in which the ruling classes had benefited from the extraordinary absorption of relative surplus value. After 1994, however, and 'thanks' to the crisis and to the deterioration in the organisational capacity of class forces, the deliberate attempts of the bourgeoisie and the 'discoveries' of policy-makers were

24 Article 67 states: 'The beginning and ending of daily working time and rest breaks shall be announced to workers at the establishment. Depending on the nature of activity, the beginning and ending times of work may be arranged differently for employees.' 
overtly focused on attaining such a level. The enactment of the NLA refers to a point of culmination within this venture.

The change in the meaning of the concept of subordination; the new definition of employer and worker, and of the terms of employment and working conditions; and the development of the forms of the new institutionality in Turkish practice and legislation - all are found among the elements of the expansion of the individual capitalist's right to control labour within and outside the workplace. The new provisions conform to the current discourses on production, covering many areas, including the transformation in the obligations of the worker; the subsequent changes in the main conceptualisations of individual labour law; the shift in the regulatory scope of labour contracts; and the introduction of new forms of contract. Today, individual labour law has become increasingly determinant in the development of norms of production which, in the absence of an international rate of profit as a limit for exploitation, have become dependent on political action.

\section{References}

Ansal, H, S. Küçükçifçi, Ö. Onaran and B. Z. Orbay (2000) Türkiye Emek Piyasasının Yapısı ve İssizlik İstanbul: Türkiye Ekonomik ve Toplumsal Tarih Vakfi.

Boratav, K (2003) Türkiye İktisat Tarihi 1908-2002 Ankara: İmge Yayınları.

Boratav, K, E. Yeldan and A. Köse (2000) Globalisation, Distribution and Social Policy: Turkey: 1980-1998 CEPA and New School for Social Research, Working Paper Series No. 20, New York, February.

Cam, S (2002) 'Neo-Liberalism and Labour within the Context of an "Emerging Market” Economy - Turkey' Capital and Class 77: 89-124.

Çetik, M and Y. Akkaya (1999) Türkiye'de Endüstri İlişkileri İstanbul: Türkiye Ekonomik ve Toplumsal Tarih Vakfi.

Dedeoğlu, S (2002) Working for Family: The Role of Women's Informal Labor in the Survival of Family-Owned Garment Ateliers in Istanbul, Turkey Michigan State University, Women and International Development Publication Series Working Paper No. 281.

Dereli, T (1998) Labour Law and Industrial Relations in Turkey The Hague: Kluwer Law International.

Esin, P (1982) İş Bölümü, Yabancılaşma ve Sosyal Politika Ankara: SBF Yayınları.

Hardt, M and A. Negri (1994) Labor of Dionysus: A Critique of the State-Form Minnesota: University of Minnesota Press.

Jessop, B (2002) The Future of the Capitalist State Cambridge: Polity Press.

Kazgan, G (1999) Tanzimattan XXI. Yüzylla Türkiye Ekonomisi: 1. Küreselle meden 2. Küreselle meye İstanbul: Altın Kitaplar.

Kepenek, Y and N. Yentürk (1996) Türkiye Ekonomisi İstanbul: Remzi Kitabevi. 
Öniş, Ziya (1998) State and Market: The Political Economy of Turkey in Comparative Perspective Istanbul: University of Bogazici.

Özveri, M (2002) 'Yargı Yoluyla Toplu İş Sözleşmelerinin Değiştirilmesi' in: Ekonomik Krizin İş Hukuku Uygulamasına Etkisi İstanbul: İstanbul Bar Association, pp. 207-256.

Selçuk, F (2002) Örgütsüzlerin Örgütlenmesi: Enformal Sektörde Işçi Örgütleri Ankara: Atölye Yayınları.

Talas, C (1992) Türkiye 'nin Açıklamalı Sosyal Politika Tarihi İstanbul: Bilgi Yayınevi.

TİSK (1995) Türk Çalışma Hayatının Sorunları ve Çözüm Önerileri Toplantısı İstanbul: TISK.

TISK (1997) Küresel Ë̆ilimler ve Çalışma Hayatı İstanbul: TİSK.

TİSK (1999) Çalışma Hayatında Esneklik İstanbul: TİSK.

Tuncay, A (2003) 'İş Güvencesi Yasası Neler Getiriyor' Çimento İşveren Dergisi 17(1): 3-18.

Tunçomağ, K (1971) Türk İş Hukuku İstanbul: Beta Yayınları.

TÜSİAD (2002) İsgücü Piyasalarının Etkisinin Artırılmasında Özel İstihdam Kurumlarının Esnek Çalışma Biçiminin Rolü İstanbul: TÜSİAD.

TÜSİAD (2010) Illerleme Bildirim Raporu

http://www.tusiad.org/_rsc/shared/file/TUSIAD-COP-2010.pdf [last accessed 29 March 2011].

Ulucan, D (2000) 'Toplu Türk İş Hukuku'nda Esneklik ve Uygulama Sorunları' in: Çalışma Hayatında Esneklik ve İş Hukukuna Etkileri İstanbul: İstanbul Bar Association, pp. 299-312.

Woodiwiss, A (1992) Law, Labor and Society in Japan: From Repression to Reluctant Recognition London \& New York: Routledge.

Yalman, G (1997) Bourgeoisie and the State, Changing Forms of Interest Representation within the Context of Economic Crisis and Structural Adjustment: Turkey during the 1980s unpublished DPhil thesis, University of Manchester, Manchester.

Yalman, G (2002) 'The Turkish State and Bourgeoisie in Historical Perspective: A Relativist Paradigm or a Panoply of Hegemonic Strategies?' in: N. Balkan and S. Sarvan (Eds.) The Politics of Permanent Crisis: Class, Ideology and State in Turkey New York: Nova Science Publishers, pp. 21-54.

Yavan, Z (1999) Structural and Non-Structural Aspects of Unemployment: A Nairees Estimation for Turkey İstanbul: TÜSİAD.

Yeldan, E (2001) Küreselleşme Sürecinde Türkiye: Bölüşüm, Birikim ve Büyüme İstanbul: İletişim Yayınları.

Yücesan-Özdemir, G (2002) 'The Exigency of Active Forms of Workplace Unionism in Turkey' South East Europe Review 4(4): 51-69. 